His passing is a profound one for his beloved wife Carol, daughter Erin, and sonin-law Scott, as well as his many students, friends, and colleagues at Vanderbilt, North Texas, and around the world and in the profession of political science. We are all lessened by his absence but strengthened immeasurably by his having touched our lives. Vanderbilt and North Texas are better places because of his time on our campuses and in our communities.

John Booth University of North Texas John Geer

Vanderbilt University Mitch Seligson

Vanderbilt University

\section{ROBERT C. TUCKER}

I cannot be entirely objective about the life and death of Robert Charles Tucker, who died, at age 92, at his home in Princeton on July 29. During the course of 50 years, Bob Tucker was my mentor, colleague, and very dear friend. He was the best man at my wedding to Katrina (Katia) vanden Heuvel, and I gave my oldest daughter, from a previous marriage, his family name as her middle name: Alexandra Tucker Cohen.

If I had not met Professor Tucker at Indiana University in 1960, when I was a young student, Russia probably would not have become the supreme subject and profession of my life. Certainly, I would not have written a biography of Bukharin, because it was Bob who pointed me toward missed alternatives in Russian and Soviet history, including the Bukharinist alternative. With his death, I have lost a large and essential part of my own life.

Nonetheless, I think I am being objective in stating that Robert C. Tucker was the preeminent and most influential American, possibly Western, scholar of Russia of his times. His scholarly influence ranged across several academic fields, from philosophy, political science, leadership studies, and comparative theory to history, and it inspired several generations of scholars well beyond the orbit of his own students at Indiana and Princeton universities.

Bob's achievements as a scholar were due, in large part I think, to four of his personal attributes. First, unlike many American academics, he was not merely a specialist but an intellectual in the fullest sense. Before first encountering Russia while serving in the U.S. embassy in Moscow during World War II, Bob was a graduate student in philosophy at Harvard University. His first book was not about Russia, but was rather a profound reinterpretation of Marx's thought as an outgrowth of Hegelianism, Philosophy and Myth in Karl Marx. Broad philosophical perspectives, not ideology, shaped Bob's subsequent thinking about politics and history as well.

Second, also unlike many Western specialists today, Bob began to read widely and deeply in Russian history while living in Moscow in the 1940s and 1950s, and he continued to do so throughout his life. As a result, he always viewed Soviet Russia in the larger context of its pre-1917 traditions, several of which, he argued, continued to shape Soviet developments for decades to come. (About this, he once had a highly publicized and fruitful quarrel with Aleksandr Solzhenitsyn, which aroused considerable indignation in that great novelist and among his followers.)

Third, and crucially, Stalinism was not an abstraction for Bob, but a phenomenon he experienced personally when he and his Russian wife, Evgeniia Pestretsova, whom he married in Moscow in 1946, were forbidden to leave the country together until after Stalin died in 1953. During those seven years of growing Soviet-American cold war, they were in constant danger of falling victim to the despot's renewed and xenophobic terror. From that intense experience came Bob's lifelong determination to explain Stalinism and, at its core, the Vohzd himself, as manifested in his definitive two-volume biography of Stalin.
But fourth, despite that harrowing experience, Bob loved Russia. It became his second Rodina, as it later became for me, and he never doubted Russia's capacity for fundamental reform, even democratic change. Not surprisingly, in the late 1960s, Andrei Sakharov was one of the Russians Bob most admired, and later, Gorbachev's effort to carry out a democratic reformation of the Soviet system was confirmation of what Bob had long thought possible. Too many Western specialists and other media commentators believe that Russia can never escape its authoritarian past, a shallow, demeaning view that has grown even more widespread in recent years. Bob, on the other hand, repeatedly told his students, "When thinking about Russia's future, never say never."

Apart from members of his family, I may have been the person closest intellectually to Robert Tucker and most influenced by him, but in the hours and days following his death, many of his devoted former students were immediately in contact with each other by way of e-mail or telephone. Our discussion was, of course, an expression of our mourning, but also of our gratitude for the privilege of having known him as a teacher and a man. All of us knew who we had lost, someone much more important and special than suggested even in the admiring obituaries in the New York Times and the Washington Post.

Boris Pasternak once remarked that an afterlife is how a person is remembered. The afterlife of Robert Charles Tucker will be at least as long and exemplary as was his earthly life. His writings will long survive him, not only the essential two-volume biography of Stalin, but also the seminal essays collected in his books The Soviet Political Mind and The Marxian Revolutionary Idea. Certainly, we, his students and friends, will never forget him or outlive his influence. Nor, I think, will our own students.

Stephen Cohen (Stiven Koen) New York University 